This item was submitted to Loughborough's Research Repository by the author.

Items in Figshare are protected by copyright, with all rights reserved, unless otherwise indicated.

\title{
In-situ temperature sensing of SOFC during anode reduction and cell operations using a multi-junction thermocouple network
}

\section{PLEASE CITE THE PUBLISHED VERSION}

http://dx.doi.org/10.1149/06801.2637ecst

\section{PUBLISHER}

(C) The Electrochemical Society

\section{VERSION}

AM (Accepted Manuscript)

\section{PUBLISHER STATEMENT}

This work is made available according to the conditions of the Creative Commons Attribution-NonCommercialNoDerivatives 4.0 International (CC BY-NC-ND 4.0) licence. Full details of this licence are available at: https://creativecommons.org/licenses/by-nc-nd/4.0/

\section{LICENCE}

CC BY-NC-ND 4.0

\section{REPOSITORY RECORD}

Ranaweera, Manoj Prasanna, and Jung-Sik Kim. 2016. "In-situ Temperature Sensing of SOFC During Anode Reduction and Cell Operations Using a Multi-junction Thermocouple Network". figshare. https://hdl.handle.net/2134/20008. 


\title{
In-Situ Temperature Sensing of SOFC during Anode Reduction and Cell Operations using a Multi-Junction Thermocouple Network
}

\author{
M.P. Ranaweera and J-S. Kim \\ Department of Aeronautical and Automotive Engineering, Loughborough University, \\ LE1 1 3TU, United Kingdom
}

\begin{abstract}
Understanding in-situ temperature distribution of a SOFC stack while in operation is very important for its performance and degradation studies. The available efforts in literature are incapable of measuring the temperature of electrodes. The proposed multijunction thermocouple network, which requires only $2 \mathrm{~N}$ thermoelements for $\mathrm{N}^{2}$ measuring points, can measure temperature directly from electrodes. A multi-junction thermocouple network having 9 measuring points was fabricated using K-type thermocouple wires $(\phi 0.5 \mathrm{~mm})$ for an in-situ measurement of the temperature distribution on a cathode $(50 \mathrm{mmx} 50 \mathrm{~mm}$, NextCell-5). The measurements were performed during an anode reduction process and during a normal cell operation while the air/fuel ratio varies. The gas temperature was measured simultaneously using a commercial K-type thermocouple from $7 \mathrm{~mm}$ adjacent to the cathode. The monitored cathode temperature via the in-situ sensors was directly correlated with the cell's OCV whilst the commercial thermocouple $7 \mathrm{~mm}$ adjacent to the electrode showed a dull change to them.
\end{abstract}

\section{Introduction}

Temperature driven performance degradations is one of the major problems that impedes the successful commercialisation of Solid Oxide Fuel Cell (SOFC) technology. Thermal cycling at high temperature (usually in the range from $600^{\circ} \mathrm{C}-900^{\circ} \mathrm{C}$ ) and uneven temperature distribution in SOFC stack leads to severe mechanical failures such as, delamination and cracking of cell components, promoting premature degradation. Attempts were made to model and predict such failures based on estimated temperature distribution over cell (1)-(4). However, in order to gain a comprehensive understanding of the causes of such phenomena and of other degradation mechanisms as well as to obtain better understandings of the performance characteristics, it's is highly beneficial to know the actual temperature distribution within a SOFC stack while it is in a normal operation.

Prevalent methods found in literature on understanding SOFC stacks' temperature distributions can be broadly classified into two domains: (a) modelling and simulation (b) experimental measurements. Among them, there are many publications regarding simulations using physical modelling techniques (5)-(12) and Artificial Neural Networks (ANN) (13)-(16). However, only a few reports pertaining to experimental temperature measurements are available. 
Experimental temperature measurements, if carried out successfully, have unique advantages over temperature simulations. Due to very complicated electro-chemical behavior of a SOFC stack, all the physical models rely on some level of simplification assumptions that may not necessarily exist in a real SOFC stack. In contrast, an ANN model of a SOFC stack does not require a functional model of the stack; it correlates the inputs and outputs based on training data with no concern over electro-chemical or thermo-electric behavior of a stack. Hence, ANN models are free from problems created by simplification assumptions. However, the accuracy of an ANN model relies greatly on the accuracy of the experimental data set used to train the model. Further, detrimental evolutions in temperature profile that are triggered by changes in operating conditions such as current, flow rate, etc(17) are not easily detectable or predictable with any type of simulations. More comprehensive way of detecting such phenomenon is temperature monitoring. Therefore, temperature monitoring has been understood as a prime necessity and different researchers have attempted it in different ways.

Extensive investigation of published researches on temperature measurement revealed their strengths and limitations. Morel et al(18) used electrochemical impedance spectroscopy (EIS) to in-situ evaluate the temperature gradient along a cell. However, this method cannot measure localised temperature. In a study by Saunders and Davy(19) to investigate the steam-methane reforming process within direct internal reforming SOFC, a commercial IR thermometer was used to measure point temperature at $10 \mathrm{~mm}$ separation on the anode along the center line of $100 \mathrm{~mm} \times 50 \mathrm{~mm}$ cell. The cell was placed inside an oven having a transparent window to make the cell visible to IR thermometer. However, this approach is not feasible with multi-cell stacks where inner cells are not exposed. Contact thermometry appears more promising than non-contact thermometry for stack temperature measurements. Razbani et al $(14,20)$ inserted 5 K-type thermocouples $(\phi$ $0.5 \mathrm{~mm})$ inside the middle cell of a 5 -cell $(110 \mathrm{~mm} \times 86 \mathrm{~mm})$ short stack to measure the temperature at the four corners and at the middle. Further, they state that researchers at Jülich $\mathrm{GmbH}$ were able to measure the temperature profile of a $5 \mathrm{~kW}$ SOFC stack by inserting 36 thermocouples. Guan et al (21) and Bedogni et al(22) have also used the method of inserting thermocouples to measure gas flow temperature at inlet and outlet of a stack.

Thermocouple thermometry appears to be promising for stack temperature monitoring. However, none of the above approaches could measure the temperature distribution in a cell level, which is more important than mere gas channel temperature. Further, the spatial resolution of measurement was also highly restricted. Embedding a large number of thermocouples to a stack to enhance spatial resolution accompanies a great technical challenge and introduces even a greater level of disturbances to the stack's operation. The proposed multi-junction thermocouple technology could overcome these barriers in a greater extent while preserving the merits of thermocouple thermometry and measures temperature distribution on the cell. A successful application of multi-junction thermocouple network for cell temperature measurement under extremely rigorous thermal condition is demonstrated and discussed.

\section{Experimental Setup}

A multi-junction thermocouple network having 9 independent temperature-measuring points was fabricated by spot welding of $\mathrm{K}$-type thermocouple wires $(\phi 0.5 \mathrm{~mm})$. The mesh-like thermocouple network has a pitch of about $10 \mathrm{~mm}$. Each node of the mesh is a 
K-type thermocouple tip. However, unlike a set of 9 individual thermocouples, this network requires only 6 thermo-elements to measure the temperature from 9 junctions. The multi-junction thermocouple concept is strongly supported by the law of intermediate materials of thermocouples, and authors of this paper have investigated its performance prior to their application in the SOFC temperature measurements (23).

In addition to the thermocouple network, a commercial K-type thermocouple was also fixed approximately $7 \mathrm{~mm}$ adjacent to the cathode for the purpose of facilitating comparisons with the network. Specific data logging software was developed by the authors for the collection of temperature and voltage data from the cell, using LabVIEW ${ }^{\mathrm{TM}}$. An NI9213 data logger was used to read the temperatures from both the thermocouple network and the commercial thermocouple. The in-built cold junction compensation of NI9213 was utilised. An NI USB-6210 data logger was used to measure the Open Circuit Voltage (OCV) from the cell.

The electrolyte supported test cell $(50 \mathrm{~mm}$ x $50 \mathrm{~mm}$ NextCell-5) was attached to the cell holder having its cathode open to atmosphere, as shown in Figure 1. The approximate locations of the 9 sensing points of the thermocouple network are represented by the labels $\mathrm{S} 1$ to $\mathrm{S} 9$. These are placed on the cathode. The commercial thermocouple was within the close proximity to $\mathrm{S} 1$.

The cathode is made of Lanthanum Strontium Manganite (LSM) and the anode is made of Nickel Oxide-Yttria Stabilised Zirconia (NiO-YSZ). The

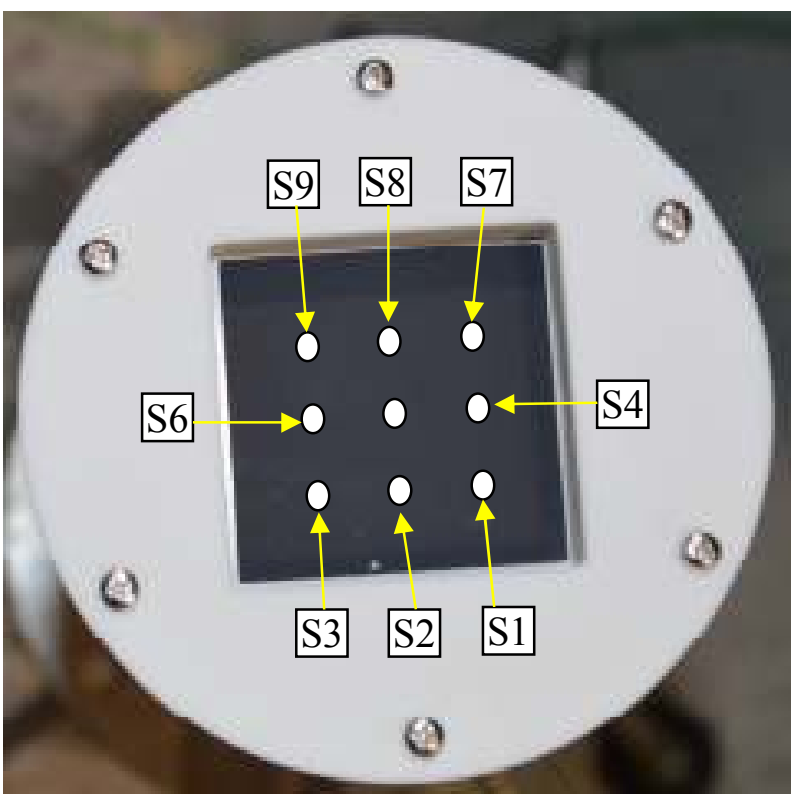

Figure 1 : Sensor locations on the cathode dimensions of the electrodes are $4 \mathrm{~cm} \times 4 \mathrm{~cm}$. The electrolyte is made of a proprietary formulation called Hionic ${ }^{\mathrm{TM}}$ whose conductivity and strength are similar to those of $10 \mathrm{ScSZ}$ and $6 \mathrm{ScSZ}$ respectively.

A Nickel mesh and a Platinum mesh were used as current collectors at the anode and cathode respectively. The thermocouple network was placed on top of the platinum mesh on the cathode. The complete test rig arrangement, with all connecting wires present is shown in Figure 2. Hydrogen is supplied from below the test rig. The oxygen required for the cathodic reactions was supplied by atmospheric air, which was drawn from the furnace surroundings.

\section{Test procedure}

The primary aim of this set up was to investigate the robustness and accuracy of the multi-junction thermocouple network in recording cell temperature measurement of SOFC. Thus, in order to assess the ability of the thermocouple network to survive in harsh conditions, no pre-heating regime was implemented. This was so as to instigate a 
situation of steep thermal loading, with the associated thermal shock and stress conditions. Since the cathode was freely in atmosphere, no external air supply was employed.

The testing process commenced with anode reduction. The cell was heated to $800^{\circ} \mathrm{C}$ under a rate of about $400^{\circ} \mathrm{C}$ per hour. A mixture composed of nitrogen gas and hydrogen gas was allowed to bleed into the anode chamber at $630 \mathrm{C}$, with respective volumetric flow rates of $180 \mathrm{~cm} 3 / \mathrm{min}$ and $15 \mathrm{~cm} 3 / \mathrm{min}$. The gas supply was continued for approximately $65 \mathrm{~min}$ allowing generous time for the anode reduction process to take place. Out of the total reduction time, approximately 40min was spent at a constant temperature of $800^{\circ} \mathrm{C}$. The cell temperature and the cathode air temperature were monitored and recorded throughout the reduction process, from both the fabricated multijunction thermocouple network as well as the commercial thermocouple.

The cell operation was commenced immediately after completing the reduction process. While the furnace was remained at $800^{\circ} \mathrm{C}$, nitrogen supply was cut off and hydrogen was introduced at different rates for different time intervals (see Table 1). Hydrogen supply was maintained at a constant pressure of $3.5 \mathrm{bar}$ throughout the experiment. The changes in flow rate of hydrogen were carried out almost instantaneously with negligible delay. The time intervals at each flow rate were determined in a way that allows sufficient time for the cell temperature to stabilise. The hydrogen flow rate was varied in order to investigate the temperature response to changing activity levels of the cell: this is the way to monitor the response of thermocouple network to temperature changes. The hydrogen flow changes were cycled to see the repeatability of measurements and hence to ensure the reliability of measurements. The furnace controller maintained the furnace temperature at $800^{\circ} \mathrm{C}$ with an accuracy of $\pm 1{ }^{\circ} \mathrm{C}$. Since the cathode was open to atmosphere, the air supply to the cathode was not controllable. The temperature and OCV were recorded at $3 \mathrm{~s}$ intervals through the data logging system.

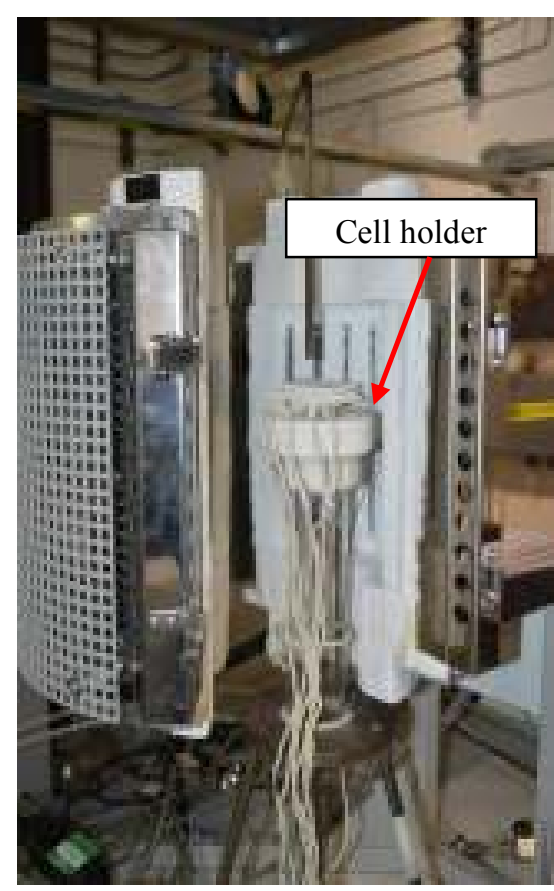

Figure 2: The test rig

Table 1: Hydrogen flow rates with approximate duration

\begin{tabular}{|c|c|c|}
\hline Setting & $\mathrm{H}_{2}$ flow rate $\left(\mathrm{cm}^{3} / \mathrm{min}\right)$ & Duration $(\mathrm{min})$ \\
\hline A & 500 & 15 \\
\hline B & 250 & 15 \\
\hline C & 150 & 15 \\
\hline D & 100 & 15 \\
\hline E & 50 & 15 \\
\hline F & 100 & 15 \\
\hline H & 150 & 30 \\
\hline H & 250 & 15 \\
\hline I & 500 & 10 \\
\hline
\end{tabular}




\section{Results and Discussion}

The temperature measured from the multi-junction thermocouple network and from the commercial thermocouple during anode reduction process is shown in Figure 3. The graph shows that the commercial thermocouple, held about $7 \mathrm{~mm}$ adjacent to the cathode, records slightly higher temperature than those recorded by the thermocouple network. Since this gap has not initiated with the commencement of the reduction process, it is difficult to relate it to the reduction process. Accepting that the resulting speculation may require further in-depth investigation, it is also not unrealistic to accept the possibility of having a temperature gradient of such a magnitude within the furnace. Further, since the accuracy of the thermocouple network was previously tested and validated with commercial thermocouples, the probability of the thermocouple network being the culprit for the aforementioned temperature difference is extremely low. The temperature measurements made from the commercial thermocouple and the thermocouple network are observed to follow the same profile. This reconfirms the accuracy of the thermocouple network and the presence of a temperature gradient between air and the cell.

It is important to note the presence of a temperature gradient across the cell during anode reduction process, which the commercial thermocouple was unable to pick. Since the experiment setup employed only one thermocouple, it is difficult to comment on whether a multiple thermocouple arrangement would be able to pick such temperature gradients.

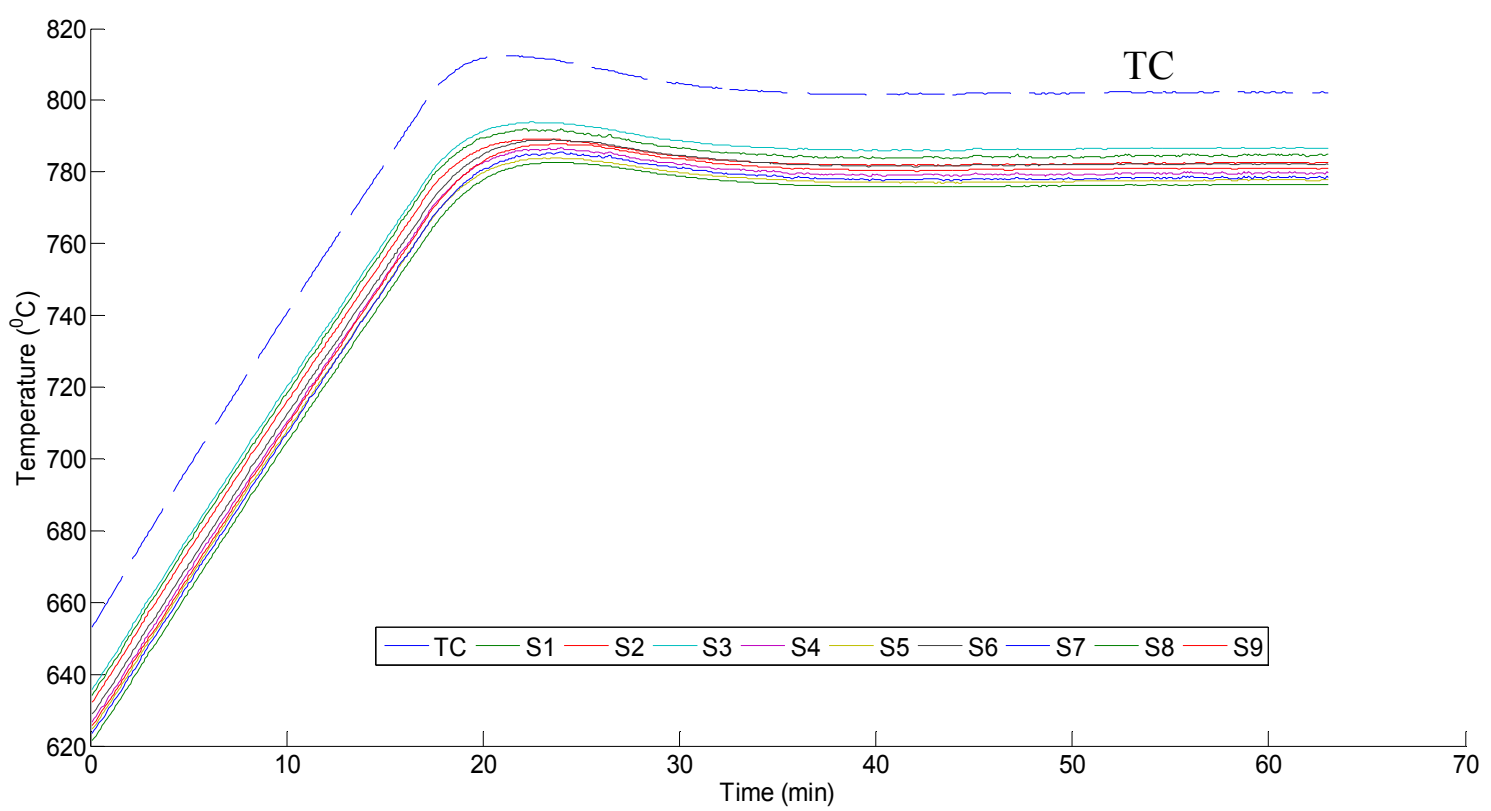

Figure 3: Temperature distribution during anode reduction (TC- thermocouple, S1:S9 - 9 points of thermocouple network)

Although nitrogen-hydrogen mixture was used without any pre-heating, the graph in Figure 3 does not show any sign of local cooling due to room temperature gas impinging directly on the cell. This suggests two possibilities, which may occur exclusively or in tandem: (a) the thermal capacity of the gas flow is insufficient to absorb sufficiently large quantity of heat from the cell, and hence not affecting a noticeable temperature drop, or 
(b) the velocity of gas flow is slow enough to pre-heat the mixture before it reaching the cell. In either case, it may be assumed that the cell temperature is fairly independent of the temperature of the supplied gas, given the fairly large difference between the operating temperature and room temperature.

Figure 4 shows the temperature distribution during normal cell operation. The marked regions (from A to I) correspond to the different hydrogen flow rates given in Table 1.This graph reveals the existence of a significant temperature gradient across even the very small region $(2 \mathrm{~cm} \times 2 \mathrm{~cm})$ that multi-junction thermocouple network occupied. Further, a very clear correlation between cell temperature and the OCV can be noted from the measurements of multi-junction thermocouple network. However, the commercial thermocouple held about $7 \mathrm{~mm}$ adjacent to cathode was almost non responsive to cell temperature changes that occurred on the cell with respect to OCV changes when Air/Fuel ratio was varied.

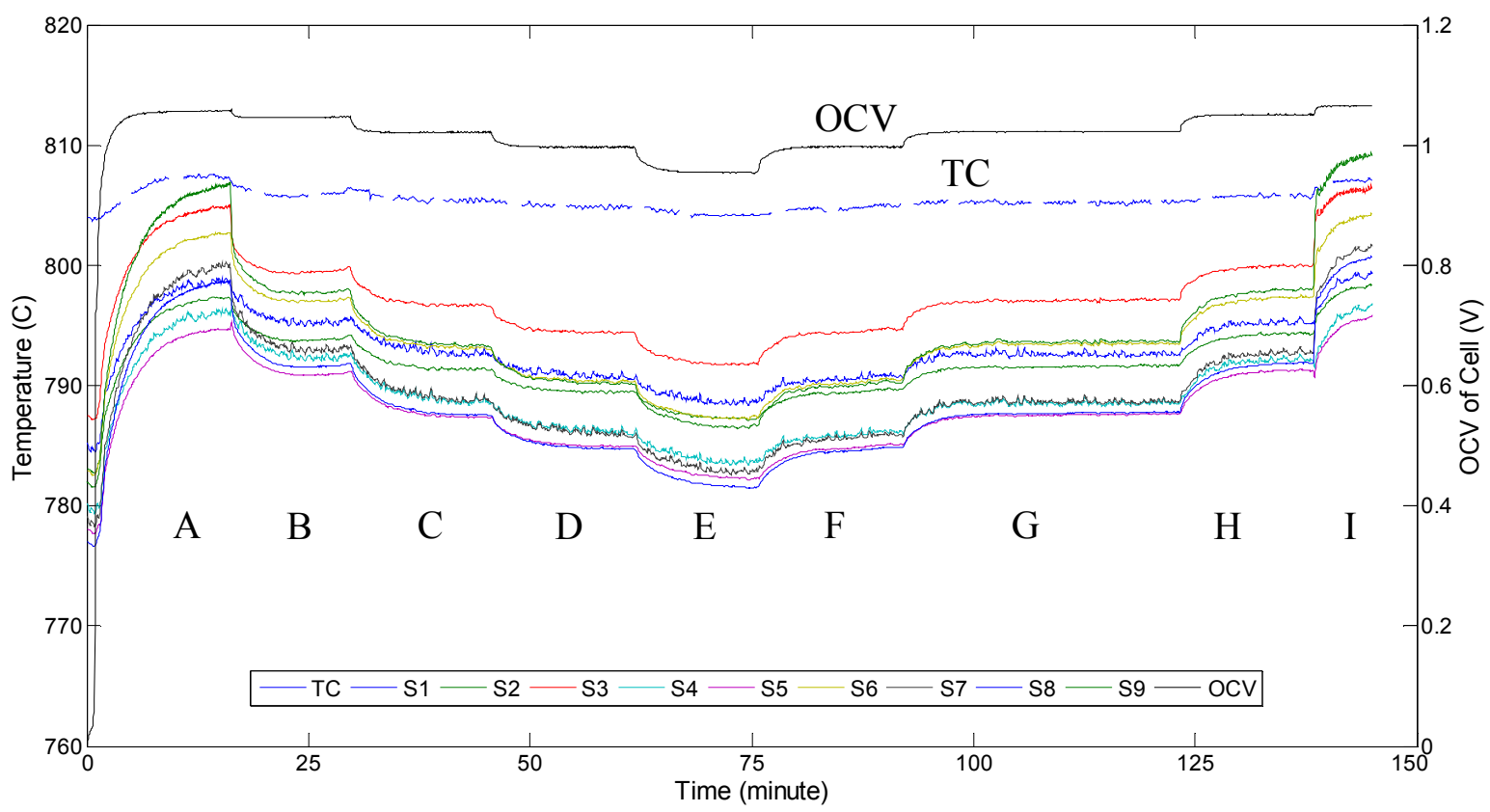

Figure 4: Temperature distribution during normal cell operation

The OCV and cell temperature values produced when hydrogen flow rate was decreased from $500 \mathrm{~cm}^{3} / \mathrm{min}$ to $5 \mathrm{~cm}^{3} /$ min were satisfactorily reproduced when the flow rate was increased from $5 \mathrm{~cm}^{3} / \mathrm{min}$ to $500 \mathrm{~cm}^{3} /$ min while going through the same flow rate settings. This ensures the repeatability of results and hence, the reliability. However, the starting OCV and cell temperature (when flow rate was $500 \mathrm{~cm}^{3} / \mathrm{min}$ - region A ) is slightly lower than that when the same flow rate was reached towards the end of experiment (region I). This behaviour should be linked with the mixture strength. The cell operation commenced immediately after the reduction process and hence, the anode chamber was filled with a great amount of nitrogen. Threfore, a diluted hydrogen mixure was present at the initial commencement of the experimental operation. However, in contrast, by the time the hydrogen flow rate was restored back to $500 \mathrm{~cm}^{3} / \mathrm{min}$ towards the end of the experiment, the nitrogen should have been flushed out completely. Therefore, a pure fuel condition was available to the anode. The marginally higher 
performance of the cell (and the correspondingly higher temperature) that is observed may be attributable to this condition, vis-à-vis the initial condition.

\section{Conclusions}

The cell temperature of a commercial SOFC test cell was measured during anode reduction and in normal cell operation by using a 9-point multi-junction thermocouple network placed on the cathode. A temperature gradient across the cell during the anode reduction process was well picked by the multi-junction thermocouple network. Further, an excellent correlation between cell temperature and OCV was recorded during cell operation, which went completely unnoticed by the commercial thermocouple placed about $7 \mathrm{~mm}$ adjacent to the cathode. Repeatability of the results revealed the reliability of the thermocouple network in measuring cell temperature. It can be concluded that cell level temperature measurements can be used to reveal and discern important fuel cell behaviours and characteristics, and that the multi-junction thermocouple network is able to discern the cell temperature with a high degree of sensitivity from point to point, and between different local areas on a small diameter cell.

\section{Acknowledgement}

The authors would like to acknowledge the support from EPSRC towards the fruitful progress made by the project.

\section{References}

1. J. Laurencin, G. Delette, B. Morel, F. Lefebvere-Joud, and M. Mupeux, J. Power Sources, 192, p344 (2009).

2. D. Sarantaridis, R.A. Rudkin, and A. Atkinson, 2008, J. Power Sources, 180, p704 (2008).

3. A. Faes, A. Nakajo, A. Hessler-Wyser, D. Dubois, A. Brisse, S. Modena, and J. Van Herle, J. Power Sources, 193, p55(2009).

4. L. Liu, G.Y. Kim, and A. Chandra, J. Power Sources, 195, p2310 (2010).

5. A.A, Kulikovsky, Intl. J. Hydrogen Energy, 35, p308 (2010).

6. J.D.J. VanderSteen and J.G. Pharoah, J. Fuel Cell Science and Technology, 3, p62 (2006).

7. E. Achenbach, J. Power Sources, 49, p333(1994)

8. H. Yakabe, T. Ogiwara, M. Hishinuma, and I. Yasuda, J. Power Sources, 102, p144 (2001).

9. S. Nagata, A. Momma, T. Kato, and Y. Kasuga, J. Power Sources, 101, p60 (2001).

10. K. Fischer and J.R. Seume, IET Renewable Power Generation, 6, p194 (2012).

11. M. Lockett, M.J.H, Simmons, and K. Kendall, J. Power Sources, 131, p243 (2004).

12. S. Kakac, A. Pramuanjaroenkij, and X.Y. Zhou, Intl. J. Hydrogen Energy, 32, p761 (2007).

13. D. Marra, M. Sorrentino, C. Pianese, and B. Iwanschitz, J. Power Sources, 241, p320 (2013).

14. O. Razbani and M. Assadi, J. Power Sources, 246, p581 (2014).

15. J. Milewski and K. Swirski, Intl. J. Hydrogen Energy, 37, p5546 (2009).

16. J. Arriagada, P. Olausson, and A.Selimovic, J. Power Sources, 112, p54 (2002). 
17. A. Nakajo, F. Mueller, J. Brouwer, J. Van herle, and D. Favrat, Intl. J. Hydrogen Energy, 37, p9269 (2012).

18. B. Morel, R. Roberge, S. Savoie, T.W. Napporn, and M. Meunier, Electrochemical and Solid-State Letters, 10, B31 (2007).

19. J.E.A. Saunders, M.H and Davy, Intl. J. Hydrogen Energy, 38, p13762 (2013).

20. O. Razbani, I. Waernhus, and M. Assadi, Applied Energy, 105, p155 (2013).

21. W.B. Guan, H.J. Zhai, L. Jin, C. Xu, and W.G. Wang, Fuel Cells, 12, p24 (2012).

22. S. Bedogni, S. Campanari, P. Lora, L. Montelatici, and P. Silva, P. J. Power Sources, 171, p617 (2007).

23. M.P Ranaweera and J-S. Kim, Intl. J. Research in Engineering and Technology, 4, p330 (2015) 